\title{
Functional screening for cellulolytic activity in a metagenomic fosmid library of microorganisms associated with coral
}

\author{
F.M.O. Sousa, S.R. Moura, C.A. Quinto, J.C.T. Dias, C.P. Pirovani and \\ R.P. Rezende \\ Departamento de Ciências Biológicas, Universidade Estadual de Santa Cruz, \\ Ilhéus, BA, Brasil \\ Corresponding author: R.P. Rezende \\ E-mail: rezende.rachel@gmail.com
}

Genet. Mol. Res. 15 (4): gmr. 15048770

Received May 9, 2016

Accepted July 15, 2016

Published October 5, 2016

DOI http://dx.doi.org/10.4238/gmr. 15048770

Copyright (C) 2016 The Authors. This is an open-access article distributed under the terms of the Creative Commons Attribution ShareAlike (CC BY-SA) 4.0 License.

ABSTRACT. Cellulases are enzymes that degrade cellulosic materials.
Cellulose is the most abundant renewable carbon resource on Earth,
and cellulases are used in various industrial sectors. Although cellulases
are obtained from a variety of sources, this is the first description of
cellulolytic activity isolated from a coral metagenomic library. A
metagenomic fosmid library of microorganisms associated with the
coral Siderastrea stellata, comprising 3552 clones, was screened for
cellulolytic activity; this allows access to non-cultivable microorganisms
by exploiting the full biotechnological potential. Clones were grown on
LB agar plates supplemented with $0.5 \%$ carboxymethylcellulose and
cellulase positive clones revealed by staining with Congo red. Using this
approach, six positive clones with cellulolytic activity were identified.
The enzymatic index (EI) of the positive clones was calculated by the
ratio between the hydrolysis zone diameter and colony diameter. All

Genetics and Molecular Research 15 (4): gmr.15048770 
positive clones had an EI greater than 1.5. Digestion of the DNA isolated from the six positive clones, using the HindIII restriction endonuclease, revealed different restriction patterns in each clone, indicating that the DNA of each clone is different. There is a growing interest for new cellulolytic enzymes in various industry sectors. Here, we present the initial selection of potential clones for cellulose degradation that could be targets for future studies of enzymatic characterization.

Key words: Coral; Metagenomic; Cellulase; Carboxymethylcellulose; Activity Gel

\section{INTRODUCTION}

The marine environment hosts a great biodiversity. The corals are an example of a system with high diversity. They are filter holobiont organisms and live with a wide variety of associated microorganisms (Lins-de-Barros et al., 2010). Of the different species of coral along the Brazilian coast, Siderastrea stellata is an endemic species, abundant on the southern coast of Bahia (Castro and Pires, 2001). Microorganisms are natural producers of enzymes with the ability to adapt different environmental conditions. The capacity of microorganisms to adapt comes from the ability of their enzymes to tolerate different environmental conditions (Suenaga, 2015).

Data indicate that more than $99 \%$ of microorganisms cannot be cultured in laboratory (Sharma et al., 2005). Metagenomic analysis is emerging as an effective alternative allowing direct access to the DNA of bacterial communities present in a given environment independent of cultivation. Metagenomics makes it possible to more widely exploit the biotechnological potential of microorganisms in the environment (Handelsman et al., 1998).

Cellulases are capable of hydrolyzing cellulose, the most abundant renewable biomass on the planet (Sandgren et al., 2005). Cellulases have applications in various industrial sectors including biofuels, feed, agriculture, textiles, and pulp and paper (Sharada et al., 2014).

Coral inhabits a saline and alkaline environment. It is possible that the enzymes of the microorganisms present in the coral microenvironment tolerate these characteristics. Therefore, the cellulases obtained from a saline and alkaline environment should be adapted to these conditions. There are no reports in the literature of studies involving cellulase research in metagenomic libraries of microorganisms associated with coral. Therefore, we screened the S. stellata metagenomic library for new cellulolytic enzymes.

\section{MATERIAL AND METHODS}

\section{Metagenomic library}

The metagenomic library was constructed using Siderastrea stellata coral samples collected in Camamu Bay (-1357'49.248", $\left.-38^{\circ} 56^{\prime} 0.132^{\prime \prime}\right)$ and send to the laboratory under refrigeration (Quito CA, unpublished results). The specimens were macerated, and then agitated for $24 \mathrm{~h}$ in sodium phosphate buffer, $\mathrm{pH} 7.5$ containing $1 \%$ sodium pyrophosphate. The sample was centrifuged at $10,000 \mathrm{~g}$ for $15 \mathrm{~min}$. DNA was extracted from the supernatant using the E.Z.N.A. ${ }^{\circledR}$ Soil DNA kit (Omega Bio-Tek, Inc., Norcross, GA, USA). The

Genetics and Molecular Research 15 (4): gmr.15048770 
metagenomics library was constructed using the CopyControl ${ }^{\mathrm{TM}}$ Fosmid Library Production Kit with the pCC1FOS Vector ${ }^{\mathrm{TM}}$ (Epicentre Biotechnologies, USA) following the manufacturer instructions. The metagenomic DNA of microorganisms associated with S. stellata was cleaved into fragments approximately $40 \mathrm{~kb}$ in length. DNA ends were repaired and the DNA cloned into the pCC1FOS vector. Later, transformants were made by introducing the DNA into host cells of Escherichia coli $\mathrm{EPI} 300^{\mathrm{TM}}$-T1R TransforMax ${ }^{\mathrm{TM}}$ (Epicentre Biotechnologies). Clones were selected on solid Luria-Bertani (LB) supplemented with $12.5 \mathrm{mg} / \mathrm{mL}$ of chloramphenicol. Clones were stored on 96 well plates containing LB broth with chloramphenicol $12.5 \mathrm{mg} / \mathrm{mL}$ and $20 \%$ glycerol at $-80^{\circ} \mathrm{C}$.

\section{Screening for cellulolytic activity}

Cellulolytic activity was evaluated by testing the hydrolysis of carboxymethylcellulose (CMC, Sigma) as revealed with Congo red (Teather and Wood, 1982). Initial tests were conducted on pools of clones. Pools with positive results were selected for individual screening. Clones for individual screening were cultivated on LB agar plates supplemented with $0.5 \%$ $\mathrm{CMC}, 0.01 \% \mathrm{~L}$-arabinose, and chloramphenicol $(12.5 \mathrm{mg} / \mathrm{mL})$. Plates were incubated at $37^{\circ} \mathrm{C}$ for 5 days. To assess CMC degradation, plates with grown clones were stained with an aqueous solution of $0.1 \%$ Congo red for $10 \mathrm{~min}$ and washed with a $1 \mathrm{M} \mathrm{NaCl}$ solution. Positive results were identified by the presence of orange halos around the colonies.

\section{Digestion of fosmidial DNA}

Fosmidial DNA was extracted from six positive clones as previously described (Sambrook et al., 1989). The DNA was evaluated for quality and quantity using a NanoDrop ${ }^{\circledR}$ 2000 spectrophotometer. Isolated fosmid DNA was digested overnight at $37^{\circ} \mathrm{C}$ with $\mathrm{HindIII}$ restriction endonuclease (Life Technologies), following the manufacturer's instructions. Enzymatic digestion was verified by agarose gel electrophoresis $(1 \% \mathrm{w} / \mathrm{v})$. Electrophoresis was performed in TAE $1 \mathrm{X}$ buffer $(40 \mathrm{mM}$ Tris-acetate and $1 \mathrm{mM}$ EDTA, $\mathrm{pH} 8.3)$ at $80 \mathrm{~V}$ for $1 \mathrm{~h}$. GeneRuler 1-kb DNA ladder (Fermentas) was used as standard molecular weight marker. Gel was visualized under ultraviolet light in Kodak EDAS 290 Electrophoresis Documentation and Analysis System (Eastman Kodak, USA).

\section{Enzymatic index}

The determination of enzymatic activity was represented by enzymatic index (EI). The EI was calculated by the ratio between the hydrolysis zone diameter and colony diameter. Measurements were made with a caliper. All measurements were made in triplicate.

\section{Crude extract production}

Crude extract was obtained from cultivation of the clones in LB medium supplemented with $0.5 \% \mathrm{CMC}, 0.01 \% \mathrm{~L}$-arabinose, and chloramphenicol $(12.5 \mathrm{mg} / \mathrm{mL})$, grown for 5 days at $37^{\circ} \mathrm{C}$ and $180 \mathrm{rpm}$. Samples were centrifuged at $10,000 \mathrm{~g}$ for $10 \mathrm{~min}$ under cooling. Cells were discarded and the supernatant used as crude extract to evaluate the cellulolytic activity. 


\section{Activity gel}

Presence of cellulolytic enzymes in crude extract of positive clones was confirmed by activity gel. The gel was done according to Alfenas (1998) with some modifications. Proteins were separated by polyacrylamide gel electrophoresis $12 \%(\mathrm{w} / \mathrm{v})$ in semi-denaturing conditions (Laemmli, 1970). After $2 \mathrm{~h}$ of running at $150 \mathrm{~V}$, the gel was immersed in an aqueous solution of $1 \%$ agarose containing $1 \% \mathrm{CMC}$ and incubated at $45^{\circ} \mathrm{C}$ for $1 \mathrm{~h}$. The gel was stained with $0.1 \%$ Congo red solution and washed with $1 \mathrm{M} \mathrm{NaCl}$.

\section{RESULTS AND DISCUSSION}

We screened 3552 coral metagenomic library clones for cellulolytic activity. We identified six clones with cellulolytic activity, accounting for $0.164 \%$ of the metagenomic library (Figure 1). Several studies have used CMC as a substrate for the screening of cellulolytic enzymes, in the absence of cellulose enrichment from libraries obtained from different substrates (Table 1). Compared to similar studies (Table 1), it can be seen that our metagenetic library produced a relatively high yield of positive clones.

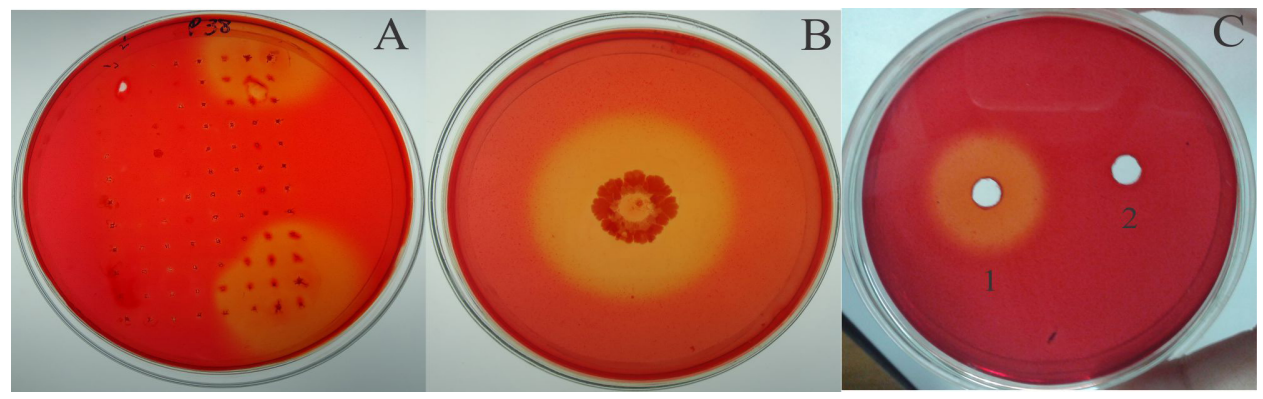

Figure 1. Activity of coral metagenomic library using carboxymethylcellulose as substrate. A. Pool coral library with several clones expressing cellulolytic activity; B. clone 19A1; C. crude extract of the clone 19A1 (1) and crude extract of Escherichia coli TransforMax ${ }^{\mathrm{TM}} \mathrm{EPI} 300^{\mathrm{TM}}-\mathrm{T} 1 \mathrm{R}$ (2).

Table 1. Comparison of different screening of metagenomic libraries without enrichment that use as carboxymethylcellulose substrate.

\begin{tabular}{l|l|c|c|c|c|c}
\hline Reference & Sample & Number of clones & Size of the insert (kb) & Vector & Positive clones & $\%$ \\
\hline Rees et al. (2003) & Crater Lake & 36,000 & 3.4 & phage $\lambda$ & 1 & 0.003 \\
\hline Feng et al. (2007) & Rabbit Cecum & 32,500 & 31.5 & Cosmid & 4 & 0.012 \\
\hline Pang et al. (2009) & Compost Soil & 100,000 & 33 & Cosmid & 4 & 0.004 \\
\hline Liu et al. (2011) & Soil & 3,024 & 75 & BAC & 1 & 0.033 \\
\hline Zhang et al. (2013) & Bursaphelenchus xylophilus & 5,000 & 3 & Puc118 & 6 & 0.12 \\
\hline Gonçalves et al. (2015) & Mangrove & 1,824 & 40 & Fosmid & 1 & 0.055 \\
\hline This study & Coral & 3,552 & 40 & Fosmid & 6 & 0.169 \\
\hline
\end{tabular}

Metagenomic analyses involving different genetic sources and vectors have been performed (Rees et al., 2003; Feng et al., 2007; Pang et al., 2009; Liu et al., 2011; Zhang et al., 2013; Gonçalves et al., 2015). Several of these studies have involved libraries with a large number of clones. Pang et al. (2009) analyzed a cosmid library of 100,000 clones derived from compost soil, and found that $0.004 \%$ of the clones showed cellulolytic activity. In contrast,

Genetics and Molecular Research 15 (4): gmr.15048770 
Zhang et al. (2013) screened 5000 clones from a Bursaphelenchus xylophilus library and found $0.12 \%$ were positive for cellulolytic activity. Taken together these results suggest that a large number of clones are not an absolute requirement for obtaining good results from functional screening.

Digestion of DNA from positive clones revealed different restriction fragment patterns (Figure 2). This indicates that our library generation consists of a randomly cloned DNA, and that the clones able to hydrolyze CMC are distinct.

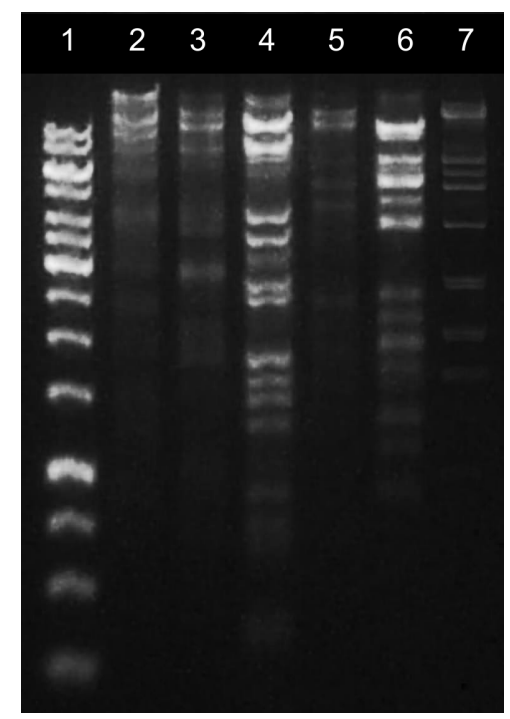

Figure 2. Profile digestion with HindIII restriction endonuclease of six positive clones for cellulolytic activity. The samples are distributed in the following order: lane 1, GeneRuler 1-kb Leader (Fermentas); lane 2, 19A1; lane 3, 19H3; lane 4, 19H12; lane 5, 38G12; lane 6, 38H10; lane 7, $18 \mathrm{H} 9$.

Measurement of the EI is a common practice and considered a simple, fast, and effective measure for enzymatic activity screening. The EI of positive clones was measured and all clones showed an EI greater than 1.5 (Table 2). EI can also be used as an initial screening tool for the selection of enzymes with higher potential activity (Florencio et al., 2012).

Table 2. Enzymatic index of the positive clones of coral metagenomic library.

\begin{tabular}{l|c}
\hline Clones & Enzimatic index* \\
\hline $18 \mathrm{H} 9$ & 1.5 \\
\hline $19 \mathrm{~A} 1$ & 2.2 \\
\hline $19 \mathrm{H} 3$ & 2.68 \\
\hline $19 \mathrm{H} 12$ & 2.3 \\
\hline $38 \mathrm{G} 12$ & 2.0 \\
\hline $38 \mathrm{H} 10$ & 2.0 \\
\hline
\end{tabular}

*Average of the index obtained in triplicate.

To confirm the presence of cellulolytic enzymes, we performed a polyacrylamide gel activity assay in semi-denaturing conditions incubated with CMC (Figure 3). This analysis revealed that the crude extract from the six positive clones did possess cellulase activity. Consistent with the EI results, clone 19H3 showed the largest hydrolysis zone.

Genetics and Molecular Research 15 (4): gmr.15048770 
Cellulases are versatile enzymes that are used in a range of industrial processes. Studies involving the search for enzymes from extreme environments, including the marine environment, have intensified. Kimes et al. (2010) analyzed microorganisms associated with coral using microarrays and demonstrated the presence of genes related to cellulose degradation. Martin et al. (2014) provided the first description of finding cellulose in a marine metagenome when they used samples of Ascophyllum nodosum algae to build a metagenomic library. However, to our knowledge, there are no reports of cellulolytic enzymes from metagenomic libraries of microorganism associated with coral.

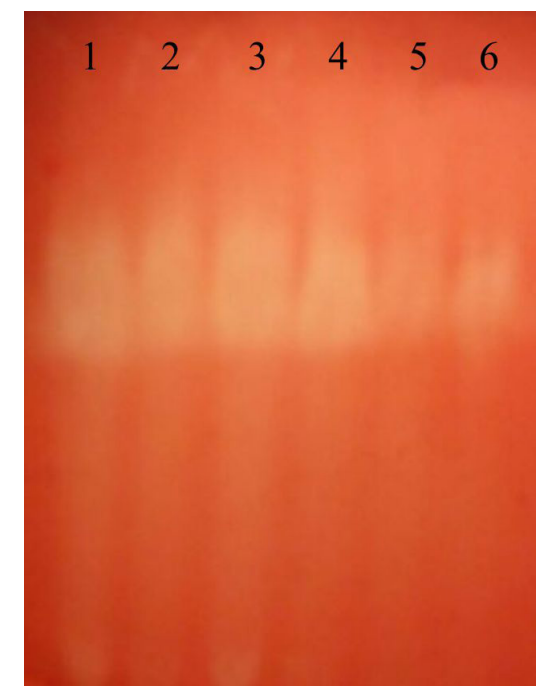

Figure 3. CMCases activity gel. The proteic extract of clones was distributed in the following order: lane 1, 18H9; lane 2, 19a1; lane 3, 19H3; lane 4, 19H12; lane 5, 38G12; lane 6, 38H10.

Studying enzymes from different sources allows us to identify and isolate enzymes adapted to the specific, and sometimes extreme, environments from which they were obtained (Suenaga, 2015). Corals live in environments with high salinity and an alkaline $\mathrm{pH}$. Therefore, enzymes obtained from this environment are likely to be able to withstand conditions of high salinity and $\mathrm{pH}$. This is important when considering industrial applications, as this sector often requires enzymes that can operate well under extreme conditions.

\section{CONCLUSION}

Here, we identified that microorganisms associated with corals are a good source of cellulolytic enzymes. In screening a relatively small library of 3552 clones, we were able to identify a large number of putative cellulases. Given the growing interest for new cellulolytic enzymes for industrial applications, these clones may be useful in future enzymatic characterization studies.

\section{Conflicts of interest}

The authors declare no conflict of interest.

Genetics and Molecular Research 15 (4): gmr.15048770 


\section{ACKNOWLEDGMENTS}

Research supported by a grant from Conselho Nacional de Desenvolvimento Científico e Tecnológico - CNPq (Proc. \#558272/2009-6). F.M.O. Sousa was supported by a doctoral fellowship from the CAPES.

\section{REFERENCES}

Alfenas AC (1998). Eletroforese de isoenzimas e proteínas afins: fundamentos e aplicações em plantas e microrganimos. Imprensa Universitária, Viçosa.

Castro CB and Pires DO (2001). Brazilian coral reefs: what we already know and what is still missing. Bull. Mar. Sci. 69: 357-371.

Feng Y, Duan CJ, Pang H, Mo XC, et al. (2007). Cloning and identification of novel cellulase genes from uncultured microorganisms in rabbit cecum and characterization of the expressed cellulases. Appl. Microbiol. Biotechnol. 75: 319-328. http://dx.doi.org/10.1007/s00253-006-0820-9

Florencio C, Couri S and Farinas CS (2012). Correlation between Agar Plate Screening and Solid-State Fermentation for the Prediction of Cellulase Production by Trichoderma Strains. Enzyme Res. 2012: 793708 http://dx.doi. org $/ 10.1155 / 2012 / 793708$.

Gonçalves ACS, dos Santos ACF, dos Santos TF, Pessoa TBA, et al. (2015). High yield of functional metagenomic library from mangroves constructed in fosmid vector. Genet. Mol. Res. 14: 11841-11847. http://dx.doi.org/10.4238/2015. October.2.17

Handelsman J, Rondon MR, Brady SF, Clardy J, et al. (1998). Molecular biological access to the chemistry of unknown soil microbes: a new frontier for natural products. Chem. Biol. 5: R245-R249. http://dx.doi.org/10.1016/S1074$\underline{5521(98) 90108-9}$

Kimes NE, Van Nostrand JD, Weil E, Zhou J, et al. (2010). Microbial functional structure of Montastraea faveolata, an important Caribbean reef-building coral, differs between healthy and yellow-band diseased colonies. Environ. Microbiol. 12: 541-556. http://dx.doi.org/10.1111/j.1462-2920.2009.02113.x

Laemmli UK (1970). Cleavage of structural proteins during the assembly of the head of bacteriophage T4. Nature 227: 680-685. http://dx.doi.org/10.1038/227680a0

Lins-de-Barros MM, Vieira RP, Cardoso AM, Monteiro VA, et al. (2010). Archaea, Bacteria, and algal plastids associated with the reef-building corals Siderastrea stellata and Mussismilia hispida from Búzios, South Atlantic Ocean, Brazil. Microb. Ecol. 59: 523-532. http://dx.doi.org/10.1007/s00248-009-9612-y

Liu J, Liu WD, Zhao XL, Shen WJ, et al. (2011). Cloning and functional characterization of a novel endo- $\beta-1,4-$ glucanase gene from a soil-derived metagenomic library. Appl. Microbiol. Biotechnol. 89: 1083-1092. http://dx.doi. org/10.1007/s00253-010-2828-4

Martin M, Biver S, Steels S, Barbeyron T, et al. (2014). Functional screening of a metagenomic library of seaweedassociated microbiota: identification and characterization of a halotolerant, cold-active marine endo-ß-1,4endoglucanase. Appl. Environ. Microbiol. http://dx.doi.org/10.1128/AEM.01194-14.

Pang H, Zhang P, Duan CJ, Mo XC, et al. (2009). Identification of cellulase genes from the metagenomes of compost soils and functional characterization of one novel endoglucanase. Curr. Microbiol. 58: 404-408. http://dx.doi.org/10.1007/ $\underline{\text { s00284-008-9346-y }}$

Rees HC, Grant S, Jones B, Grant WD, et al. (2003). Detecting cellulase and esterase enzyme activities encoded by novel genes present in environmental DNA libraries. Extremophiles 7: 415-421. http://dx.doi.org/10.1007/s00792-003$\underline{0339-2}$

Sambrook J, Fritsch EF and Maniatis T (1989). Molecular cloning: a laboratory manual. 2nd edn. Cold Spring Harbor Laboratory Press, Cold Spring Harbor.

Sandgren M, Ståhlberg J and Mitchinson C (2005). Structural and biochemical studies of GH family 12 cellulases: improved thermal stability, and ligand complexes. Prog. Biophys. Mol. Biol. 89: 246-291. http://dx.doi.org/10.1016/j. pbiomolbio.2004.11.002

Sharada R, Venkateswarlu G, Venkateswar S and AnandRao M (2014). Applications of cellulases. IJPCBS 4: 424-437.

Sharma R, Ranjan R, Kapardar RK and Grover A (2005). 'Unculturable' bacterial diversity: An untapped resource. Curr. Sci. 89: $72-77$.

Suenaga H (2015). Targeted metagenomics unveils the molecular basis for adaptive evolution of enzymes to their environment. Front. Microbiol. 6: 1018 http://dx.doi.org/10.3389/fmicb.2015.01018.

Genetics and Molecular Research 15 (4): gmr.15048770 
Teather RM and Wood PJ (1982). Use of Congo red-polysaccharide interactions in enumeration and characterization of cellulolytic bacteria from the bovine rumen. Appl. Environ. Microbiol. 43: 777-780.

Zhang L, Fan Y, Zheng H, Du F, etal. (2013). Isolation and characterization of a novel endoglucanase from a Bursaphelenchus xylophilus metagenomic library. PLoS One 8: e82437 http://dx.doi.org/10.1371/journal.pone.0082437.

Genetics and Molecular Research 15 (4): gmr. 15048770 